\title{
TOTAL EXCHANGEABLE POTASSIUM AND CHLORIDE AND TOTAL BODY WATER IN HEALTHY MEN OF VARYING FAT CONTENT
}

\author{
By E. A. BOLING,* W. L. TAYLOR, C. ENTENMAN, ANd A. R. BEHNKE, JR. \\ (From the Biological and Medical Sciences Division, U. S. Naval Radiological Defense \\ Laboratory, San Francisco, Calif.)
}

(Submitted for publication September 20, 1960; accepted June 7, 1962)

During the past few years various attempts have been made to develop an improved standard of reference for comparison of those parameters of body composition which refer largely to lean body mass. Weir measured carcass chloride in dogs and found poor correlation between carcass chloride and body weight (1). He found, however, better correlation between carcass chloride and fatfree carcass weight (2). Corsa and co-workers (3) pointed out the theoretical desirability of relating total exchangeable potassium $\left(\mathrm{K}_{\mathrm{e}}\right)$ to lean body mass or to a parameter closely related to lean body mass. Cheek and West (4) found that $\mathrm{K}_{\mathrm{e}}$, carcass potassium, $\mathrm{Cl}_{\mathrm{e}}$, and carcass chloride in rats were closely related to both fat-free carcass weight and to total body water (TBW). Muldowney, Crooks, and Bluhm $(5,6)$ measured $\mathrm{K}_{\mathrm{e}}$, $\mathrm{Cl}_{e}$, antipyrine space, plasma volume, and red cell mass in adult human beings and compared all these except antipyrine space with lean body mass, derived from antipyrine space, and with creatinine excretion. They found that the correlation of each parameter with the derived lean body mass was significantly better than its correlation with body weight. McMurrey and co-workers (7) measured total exchangeable chloride, potassium, and sodium $\left(\mathrm{Cl}_{e}, \mathrm{~K}_{\mathrm{e}}\right.$, and $\left.\mathrm{Na}_{\mathrm{e}}\right)$, red cell mass, plasma volume, and TBW in a group of ten healthy men and ten healthy women. Their data show much better correlation of these parameters with TBW than with body weight.

Recently, O'Meara, Birkenfeld, Gotch, and Edelman (8) have found that the mixing of administered $\mathrm{K}^{42}$ is prolonged in subjects who have edema. It was concluded by these authors that equilibration times should be extended to 40 hours when measuring $\mathrm{K}_{\mathrm{e}}$ in sick patients. Because of the short half-life of $\mathrm{K}^{\mathbf{4}}$, this makes the measurement

\footnotetext{
* Present address : Medical Service, Veterans Administration Hospital, Boston, Mass.
}

much more difficult to perform. Recently, however, apparatus has become available that makes it convenient to measure $K_{e}$ after a mixing time of 40 hours, using a dose of only 50 microcuries of $\mathrm{K}^{42}(9,10)$.

In order to study the inter-relationships of parameters of body composition, these should be determined simultaneously in each subject. Data permitting such comparisons for healthy adults are scarce. Also, values for $\mathrm{K}_{\mathrm{e}}$ in healthy adults with equilibration times of 40 hours are few. Finally, the effect of obesity on these inter-relationships is not known. In order to gather additional values permitting the study of these relationships, the present study was undertaken. Thirty-five healthy men were studied. They were chosen so that a wide range of fat content was encompassed. Simultaneous estimations of $\mathrm{TBW}, \mathrm{K}_{\mathrm{e}}$, and $\mathrm{Cl}_{\mathrm{e}}$ were made using tritiated water, $\mathrm{K}^{42}$, and $\mathrm{Br}^{82}$ as the tracers, respectively. The results confirm the close relationships previously reported between the magnitude of $\mathrm{K}_{\mathrm{e}}$ and $\mathrm{Cl}_{\mathrm{e}}$, estimated by $\mathrm{Br}^{82}$, and the magnitude of TBW. The ratio $K_{e}$ : TBW was significantly higher in muscular men (weightlifters) than in randomly selected or obese men. In addition, the values for the ratio $\mathrm{Cl}_{e}$ : TBW tended to be higher in obese than in average men, and higher in average than in lean men.

\section{METHODS}

Subjects. Thirty-seven healthy men were studied. The first 21 were selected at random. Subsequent selections were made so that only obese or unusually lean men were selected. Food and water were allowed at will during the first 16 hours of the experiment. A diet low in potassium was prescribed for the remaining 24 hours.

Dosage. Each person received an intravenous injection of 50 microcuries of $\mathrm{K}^{42}$, given 40 hours prior to equilibrium sampling, and an intravenous injection of $5 \mathrm{mi}-$ crocuries of $\mathrm{Br}^{82}$, given 24 hours prior to equilibrium sampling. An intravenous injection of 1 millicurie of $\mathrm{H}^{3}$ as tritiated water was given each subject on the morning 
equilibrium of $\mathrm{K}^{42}$ and $\mathrm{Br}^{82}$ distribution occurred. All injections were sterile and isotonic and were administered with calibrated syringe-pipettes, modified after Chaney (11) and delivering $20.0 \pm .01 \mathrm{ml}$. The radiation dose from these three doses of isotope is less than $0.16 \mathrm{rad}$.

Sampling. Subjects saved their urine during the entire experiment for estimation of tracer excretion. On the morning of equilibrium sampling, neither food nor water was permitted. Two successive spot urine samples were collected, usually at 9:30 and 11:30 a.m., for determination of potassium equilibrium specific activity. Equilibrium venous whole blood samples were withdrawn. The serum was separated and used to determine equilibrium $\mathrm{Br}^{82}: \mathrm{Cl}$ specific activity. At this time the tritiated water dose was given. Two and 3 hours later, venous whole blood was collected, and the serum was separated and stored in a freezer for tritiated water analyses.
Counting. All samples containing $\mathrm{Br}^{82}$ were counted as $15-\mathrm{ml}$ aliquots in a $\mathrm{NaI}: \mathrm{Tl}$ well counter. Each serum was counted in triplicate. For each, 10,000 counts were collected at counts: background ratios of about 4:1. Urine excretion samples were counted in duplicate. Duplicate dilutions of the injected material were counted in triplicate.

The samples containing $\mathrm{K}^{42}$ were counted as $80-\mathrm{ml}$ volumes in a beta well counter $(9,10)$. To those urine samples containing both $\mathrm{K}^{42}$ and $\mathrm{Br}^{82}$, a measured excess of $\mathrm{AgNO}_{3}$ was added and the samples were filtered through asbestos. This removed all detectable $\mathrm{Br}^{82}$. The filtrate was then used for $\mathrm{K}^{42}$ counting. Excretion samples were counted in duplicate. Equilibrium samples were counted in quadruplicate, with at least 10,000 counts for each sample. Counts: background ratios varied between $4: 1$ and $12: 1$.

TABLE I

Body composition in healthy men *

\begin{tabular}{|c|c|c|c|c|c|c|c|c|c|c|c|c|}
\hline \multirow[t]{2}{*}{ Subject } & \multirow[t]{2}{*}{ Age } & \multirow{2}{*}{$\frac{\begin{array}{c}\text { Body } \\
\text { weight }\end{array}}{k g}$} & \multicolumn{2}{|c|}{ TBW } & \multicolumn{3}{|c|}{$\mathrm{Cl}_{\mathrm{e}}$} & \multicolumn{3}{|c|}{$\mathrm{K}_{\bullet}$} & \multirow[t]{2}{*}{$\mathrm{Cl}_{\mathbf{0}}: \mathrm{K}_{\mathbf{0}}$} & \multirow{2}{*}{$\frac{\begin{array}{c}\mathrm{K}^{42} \text { s.a. } \\
\text { difference }\end{array}}{\%}$} \\
\hline & & & $L$ & $\% w t$ & $m E q$ & $\underset{T B W}{m E q / L}$ & $m E q / k g$ & $m E q$ & $\underset{T B W}{m E q / L}$ & $m E q / k g$ & & \\
\hline ARB & 56 & 93.6 & 48.5 & 51.8 & 2,561 & 52.8 & 27.3 & 4,242 & 87.5 & 45.3 & 0.604 & 2.45 \\
\hline GC & 21 & 62.7 & 39.1 & 62.4 & & & & 3,277 & 84.3 & 52.3 & & 1.90 \\
\hline BV & 32 & 73.6 & 38.8 & 52.7 & & & & 3,378 & 87.1 & 45.9 & & 9.20 \\
\hline NW & 20 & 64.3 & 37.6 & 58.5 & 1,804 & 48.0 & 28.0 & 3,534 & 94.2 & 55.0 & 0.510 & \\
\hline MS & 43 & 52.4 & 30.6 & 58.4 & 1,532 & 50.1 & 29.2 & 2,434 & 79.5 & 46.4 & 0.629 & \\
\hline MO & 45 & 82.2 & 44.8 & 54.4 & 2,375 & 53.0 & 28.9 & 3,976 & 88.9 & 48.4 & 0.597 & 0.90 \\
\hline SF & 36 & 69.0 & 38.4 & 55.6 & 1,947 & 50.7 & 28.2 & 3,377 & 87.9 & 48.9 & 0.576 & 4.19 \\
\hline ALS & 45 & 75.4 & 40.0 & 53.0 & 2,117 & 52.9 & 28.0 & 3,316 & 82.9 & 44.0 & 0.638 & 3.40 \\
\hline JD & 22 & 81.8 & 50.0 & 61.1 & & & & 4,404 & 88.1 & 53.8 & & 0.53 \\
\hline EBK & 26 & 74.3 & 43.4 & 58.4 & & & & 4,010 & 92.4 & 54.0 & & 2.11 \\
\hline MK & 24 & 79.5 & 41.7 & 52.4 & 2,248 & 54.0 & 28.3 & 3,700 & 88.8 & 46.5 & 0.607 & 1.49 \\
\hline JS & 21 & 74.1 & 44.3 & 59.8 & 2,276 & 51.4 & 30.7 & 3,781 & 85.4 & 51.0 & 0.602 & 1.08 \\
\hline RO'D & 23 & 62.7 & & & 2,001 & & 31.9 & 3,682 & & 58.7 & 0.543 & 2.12 \\
\hline AY & 34 & 85.4 & 49.0 & 57.4 & 2,665 & 54.4 & 31.2 & 4,008 & 81.8 & 48.9 & 0.665 & 0.00 \\
\hline MSh & 30 & 87.0 & 46.8 & 53.8 & 2,248 & 48.0 & 25.8 & 3,988 & 85.2 & 45.8 & 0.563 & 1.78 \\
\hline DF & 22 & 73.6 & 43.0 & 58.4 & 2,240 & 52.1 & 30.4 & 3,862 & 89.8 & 52.5 & 0.580 & 1.60 \\
\hline $\mathbf{K F}$ & 28 & 89.5 & 52.4 & 58.5 & 2,686 & 51.2 & 30.0 & 4,572 & 87.2 & 51.1 & 0.587 & 1.93 \\
\hline TC & 34 & 81.2 & 45.0 & 55.4 & 2,326 & 51.8 & 28.6 & 3,830 & 85.1 & 47.2 & 0.607 & 0.41 \\
\hline NS & 23 & 77.6 & 48.8 & 62.9 & 2,373 & 48.6 & 30.6 & 4,307 & 88.2 & 55.5 & 0.551 & 1.52 \\
\hline DJ & 25 & 77.7 & 43.2 & 55.7 & 2,235 & 51.7 & 28.8 & 3,662 & 84.8 & 47.1 & 0.610 & 3.38 \\
\hline OS & 29 & 67.6 & 38.8 & 57.4 & 1,955 & 50.4 & 28.9 & 3,313 & 85.4 & 49.0 & 0.590 & 5.16 \\
\hline $\mathrm{HC}$ & 37 & 58.2 & 38.0 & 65.3 & 1,863 & 49.0 & 32.0 & 3,019 & 79.5 & 51.9 & 0.617 & 1.42 \\
\hline $\mathrm{TA}$ & 39 & 98.6 & 47.9 & 48.6 & 2,480 & 51.8 & 25.1 & 3,940 & 82.2 & 40.0 & 0.629 & 0.37 \\
\hline JF & 25 & 70.9 & 45.5 & 64.2 & 2,236 & 49.1 & 31.5 & 4,265 & 93.7 & 60.2 & 0.524 & 0.30 \\
\hline LG & 35 & 74.8 & 46.5 & 52.2 & 2,304 & 49.5 & 30.8 & 4,287 & 92.0 & 57.2 & 0.539 & 0.54 \\
\hline $\mathrm{KJ}$ & 24 & 94.6 & 57.5 & 60.8 & 2,897 & 50.4 & 30.6 & 5,196 & 90.4 & 54.9 & 0.558 & 0.62 \\
\hline TC & 26 & 79.3 & 49.7 & 62.7 & 2,299 & 46.3 & 30.0 & 4,611 & 92.9 & 58.1 & 0.499 & 1.69 \\
\hline $\mathrm{EH}$ & 22 & 83.4 & 51.6 & 61.9 & 2,463 & 47.8 & 29.5 & 4,956 & 96.0 & 59.4 & 0.497 & 1.99 \\
\hline $\mathrm{JH}$ & 30 & 78.6 & 53.0 & 67.4 & 2,801 & 52.9 & 35.6 & 4,625 & 87.3 & 58.8 & 0.606 & \\
\hline J B & 41 & 130.7 & 61.1 & 46.7 & 4,021 & 65.8 & 30.7 & 5,282 & 86,4 & 40.4 & 0.761 & 0.27 \\
\hline JD & 28 & 104.2 & 50.4 & 48.3 & 3,311 & 65.7 & 31.8 & 4,329 & 85.9 & 41.5 & 0.765 & 0.12 \\
\hline RR & 26 & 124.6 & 52.5 & 42.1 & 3,617 & 68.9 & 29.0 & 4,378 & 83.4 & 35.1 & 0.826 & 0.76 \\
\hline FF & 31 & 111.9 & 49.5 & 44.2 & 2,638 & 53.3 & 23.5 & 4,211 & 85.1 & 37.6 & 0.626 & 2.80 \\
\hline CR & 27 & 83.6 & 45.8 & 54.8 & 2,458 & 53.7 & 29.4 & 4,164 & 90.9 & 49.8 & 0.590 & 0.30 \\
\hline $\mathrm{JBe}$ & 28 & 122.3 & 54.9 & 44.9 & 3,058 & 55.7 & 25.0 & 4,709 & 85.8 & 38.5 & 0.649 & 0.36 \\
\hline LC & 39 & 170.4 & & & 3,562 & & 20.9 & 6,006 & & & 0.593 & 0.5 \\
\hline $\mathrm{KT}$ & 35 & 115.0 & 53.7 & 46.7 & 2,886 & 53.8 & 25.1 & 4,774 & 88.9 & 41.5 & 0.604 & 1.33 \\
\hline Mean & 30.6 & 86.1 & 46.3 & $\begin{array}{c}56.0 \\
r=0.83\end{array}$ & 2,384 & $\begin{array}{c}51.2 \\
r=0.95\end{array}$ & $\begin{array}{c}28.8 \\
r=0.90\end{array}$ & 4,092 & $\begin{array}{c}87.3 \\
r=0.96\end{array}$ & $\begin{array}{c}48.7 \\
r=0.79\end{array}$ & $\begin{array}{c}0.586 \\
r=0.90\end{array}$ & 1.8 \\
\hline
\end{tabular}

* $\mathrm{TBW}=$ total body water, $\mathrm{Cl}_{\mathrm{e}}=$ total exchangeable chloride, $\mathrm{K}_{\mathrm{e}}=$ total exchangeable potassium, and s.a. $=$ specific activity . 
Serum samples containing $\mathrm{H}^{3}$ were kept frozen between collection and assay. They were then thawed, vacuum distilled from the frozen state, and counted in a liquid scintillation spectrometer, by a method similar to that of Leibman, Gotch, and Edelman (12).

Chemical determinations. Potassium determinations were done by internal standard flame photometry, with a Baird Associates flame photometer. Dilutions were prepared in duplicate, each dilution was read on each of 2 days, and all values were averaged. Serum chloride determinations were done in duplicate on each of 2 days by a potentiometric titration based on the method of Sanderson (13).

Calculations. In calculating $\mathrm{K}_{\mathbf{e}}$, all beta well counter data were first corrected for background and for radioactive decay. A specific gravity correction was necessary $(10,14)$. The reduced data were used to calculate $K_{e}$ by the standard formula (15).

In calculating $\mathrm{Cl}_{e}$, the $\mathrm{NaI}$ : $\mathrm{T} 1$ scintillation well counting rates were corrected for background. Since the $\mathrm{Br}^{82}$ samples also contained $\mathrm{K}^{42}$, it was necessary to correct for this. For the $\mathrm{Br}^{82}$ excretion urine sample, the correction was based upon the ratio, $\mathrm{K}^{42}$ counts per minute per $15-\mathrm{ml}$ sample ( $\mathrm{NaI}: \mathrm{T} 1$ well counter): $\mathrm{K}^{42}$ counts per minute per 80-ml sample (beta well counter).

This method for separating $\mathrm{K}^{42}$ and $\mathrm{Br}^{82}$ was sufficiently precise for use in estimating the urinary excretion of $\mathrm{K}^{42}$ and $\mathrm{Br}^{82}$. For the equilibrium $\mathrm{Br}^{82}$ serum samples, the correction for the $\mathrm{K}^{42}$ contribution to the $\mathrm{NaI}: \mathrm{Tl}$ rate was also based upon this ratio. It must be emphasized that this correction was always small, never more than $17 \mathrm{cpm}$ for any of these subjects, compared with the total serum counting rate of 400 to $600 \mathrm{cpm}$. Consequently, errors in the estimation of these $\mathrm{K}^{42}$ contributions to the $\mathrm{NaI}$ : $\mathrm{Tl}$ counting rates could have no significant effect upon the values for $\mathrm{Cl}_{e}$.

TBW was calculated by the standard formula (15). The values represent water at $20^{\circ} \mathrm{C}$.

\section{RESULTS}

The values for $\mathrm{K}_{\mathrm{e}}, \mathrm{Cl}_{\mathrm{e}}$, and TBW are given in Table I. The age and weight of each subject is listed. Values are given for $\mathrm{K}_{\mathrm{e}}, \mathrm{Cl}_{\mathrm{e}}, \mathrm{TBW}$, and for the ratios $\mathrm{Cl}_{\mathrm{e}}$ : weight, $\mathrm{Cl}_{\mathrm{e}}$ : TBW, $\mathrm{K}_{\mathrm{e}}$ : weight, $\mathrm{K}_{\mathrm{e}}: \mathrm{TBW}, \mathrm{Cl}_{\mathrm{e}}: \mathrm{K}_{\mathrm{e}}$, and TBW : weight. The mean of each parameter and each ratio is given. Correlation coefficients are listed. The difference between the $\mathrm{K}^{42}: \mathrm{K}^{39-41}$ specific activity of the first equilibrium urine sample in each subject and that of the second sample, voided about 2 hours later, is given as per cent of the mean specific activity for those two samples.

\section{DISCUSSION}

The regressions of $\mathrm{TBW}, \mathrm{K}_{\mathrm{e}}$, and $\mathrm{Cl}_{\mathrm{e}}$ on body weight in this group of men all intersect the ordi-

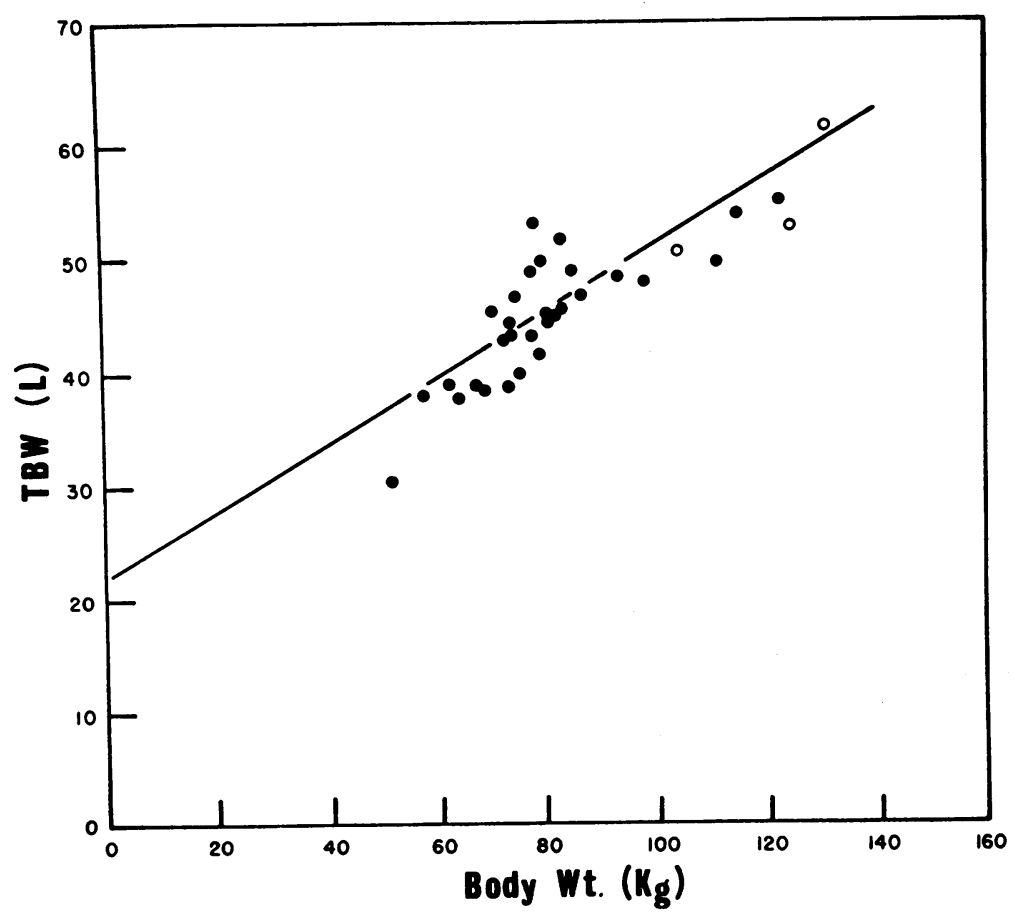

Fig. 1. Linear REgression of TBW Against body Weight For Whole GROUP. For values represented by 0 in Figures $1-4$ and 7 see Discussion. cussion. 


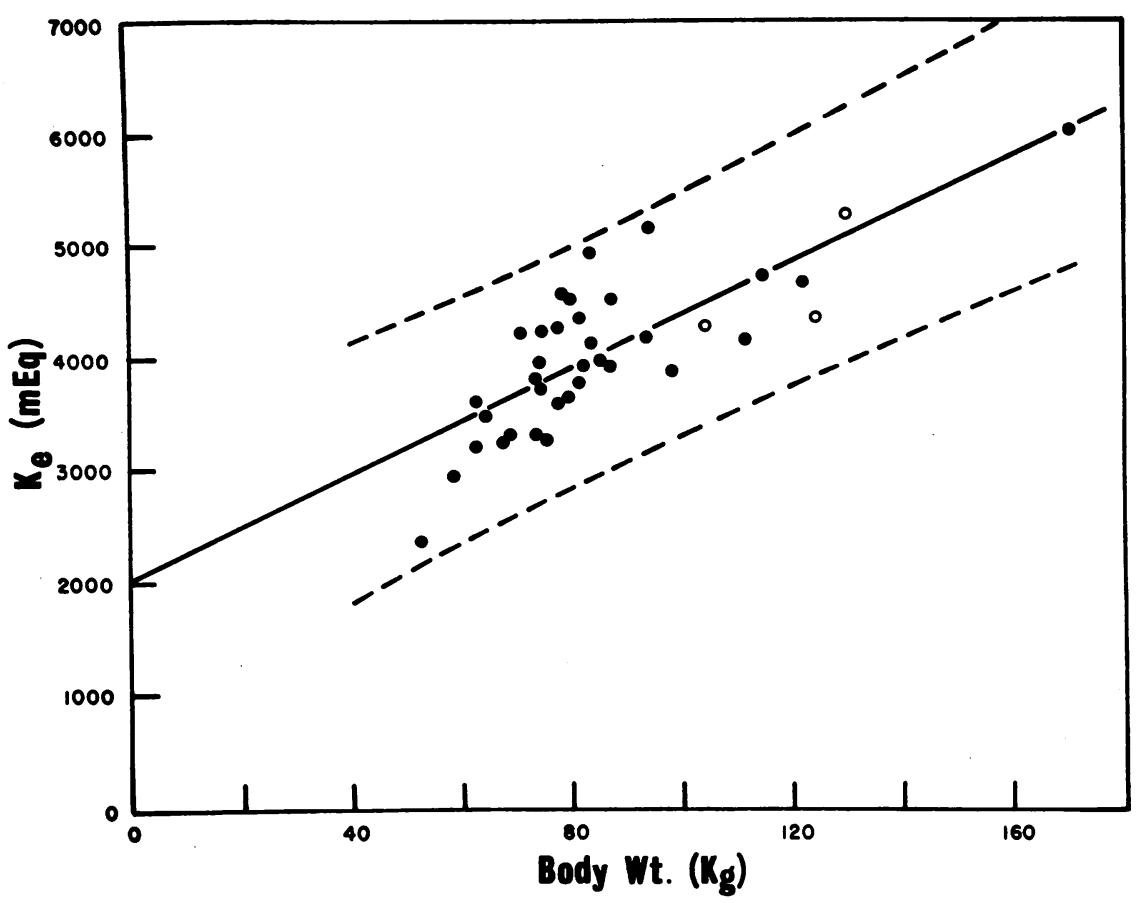

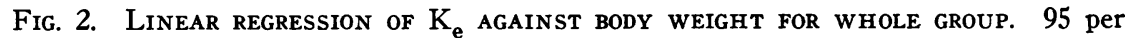
cent confidence limits for individual values shown.

nate substantially above zero. The regression equations are: a) $\mathrm{TBW}=0.288$ weight +22.08 $\mathrm{L}$, b) $\mathrm{K}_{\mathrm{e}}=23.16$ weight $+2098 \mathrm{mEq}$, and c) $\mathrm{Cl}_{\mathrm{e}}=16.28$ weight $+1008 \mathrm{mEq}$ (Figures $1-3$ ). The regression coefficients would be larger, and the zero-weight intercepts smaller, if the group did not contain a large proportion of obese individuals. Thus, when these regressions are computed excluding those eight men who were deliberately selected because they were obese, the resulting rgressions are : a) $\mathrm{TBW}=0.500$ weight $+6.43 \mathrm{~L}$, b) $\mathrm{K}_{\mathrm{e}}=48.77$ weight $+198 \mathrm{mEq}$, and c) $\mathrm{Cl}_{\mathrm{e}}=26.98$ weight $+210 \mathrm{mEq}$. It is seen that all three regression lines pass substantially closer to the origin when the eight markedly obese men are excluded. The origin lies within the 95 per cent confidence limits for all three lines.

In contrast, the regression of $\mathrm{K}_{\mathrm{e}}$ on TBW for the entire group, including the fat men, passes close to the origin (Figure 4). The same is true for $\mathrm{Cl}_{\mathrm{e}}$ against TBW (Figure 5). The regressions are : a) $\mathrm{K}_{\mathrm{e}}=92.97 \mathrm{TBW}-297 \mathrm{mEq}(\mathrm{r}=0.96)$, and b) $\mathrm{Cl}_{\mathrm{e}}=54.53 \mathrm{TBW}-149 \mathrm{mEq}(\mathrm{r}=0.95)$. The origin lies within the 95 per cent confidence limits for both regression lines.
In all of the graphic presentation, the data from subjects JB, JD, and RR, representing the determinations from 1 week, are plotted as open circles. These points lie clearly within the group when the comparisons $\mathrm{TBW}$ : weight, $\mathrm{K}_{\mathrm{e}}$ : TBW, and $\mathrm{K}_{\mathrm{e}}$ : weight are considered. However, for these comparisons in which $\mathrm{Cl}_{e}$ appears, i.e., for $\mathrm{Cl}_{e}$ : weight, $\mathrm{Cl}_{\mathrm{e}}$ : TBW, and $\mathrm{Cl}_{\mathrm{e}}$ : TBW against $\mathrm{TBW}$ : weight, they are clearly different from the group. These points are not seen in Figure 5 because all 3 fall completely outside the scale which was chosen to depict $\mathrm{Cl}_{\mathrm{e}}$ against $\mathrm{TBW}$. Because of this extreme divergence, these values were not used in the statistical analysis. Although no clue could be found, it is probable that a systematic laboratory error occurred in the measurement of $\mathrm{Cl}_{\mathrm{e}}$ for these 3 subjects.

Ljunggren (16) measured TBW, $\mathrm{K}_{\mathrm{e}}$, a corrected thiosulfate distribution volume, and a distribution volume of $\mathrm{Br}^{82}$ in normal and obese men and women. From mathematical interpretations, he concluded that the sex differences evident when either chloride space, thiosulfate space, or $K_{e}$ was compared with either weight or TBW, could be explained on the basis of variation in relative fat 


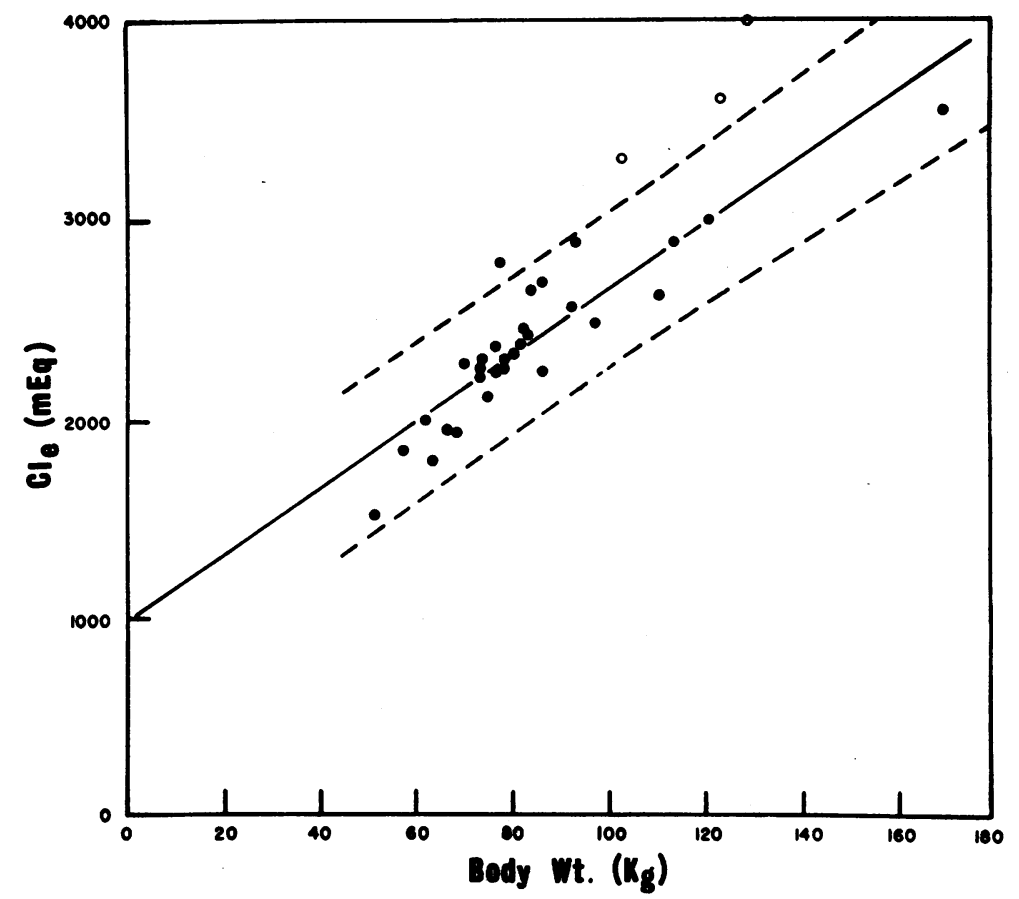

Fig. 3. Linear Regression of $\mathrm{Cl}_{\mathrm{e}}$ AgAinst body Weight FOR WhOle Group. 95 per cent confidence limits for individual values shown.

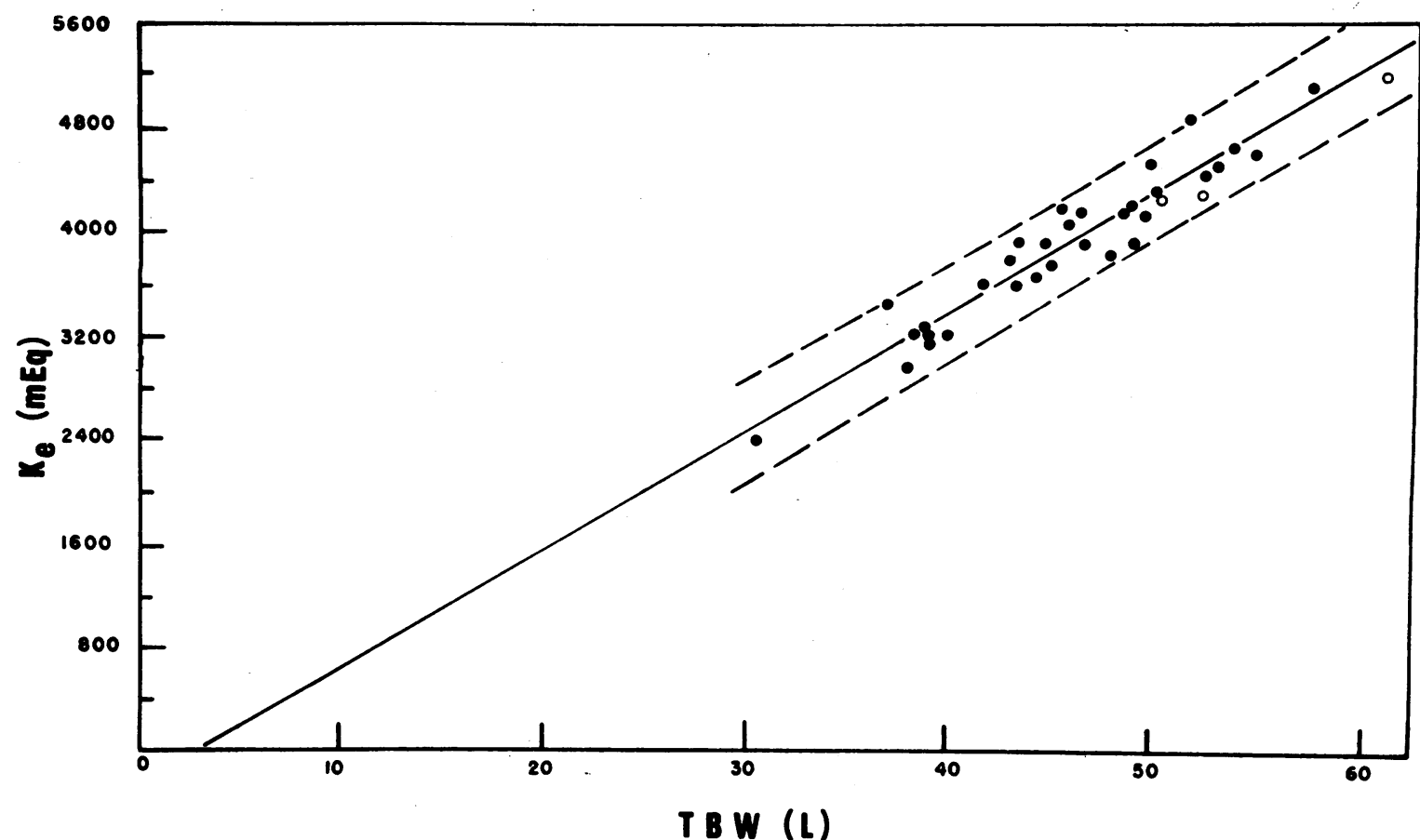

Fig. 4. Linear REgRESSION OF K. AgAinst TBW FOR WHOLE GrOUP, INCLUding fat group. 95 per cent confidence limits for individual values shown. 


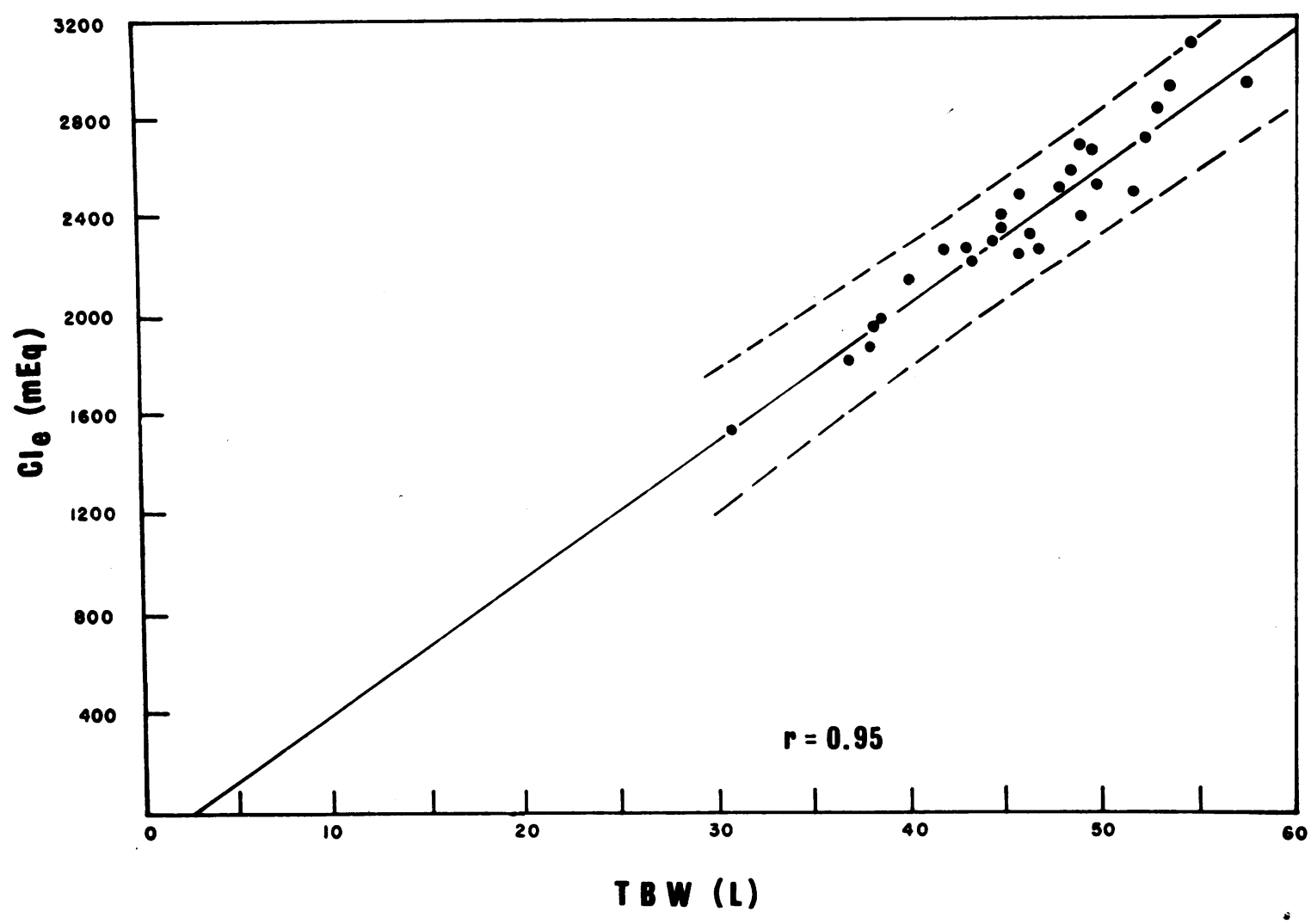

Fig. 5. Linear Regression of $C_{L_{e}}$ Against TBW for W HOle group, including fat group. 95 per cent confidence limits for individual values shown.

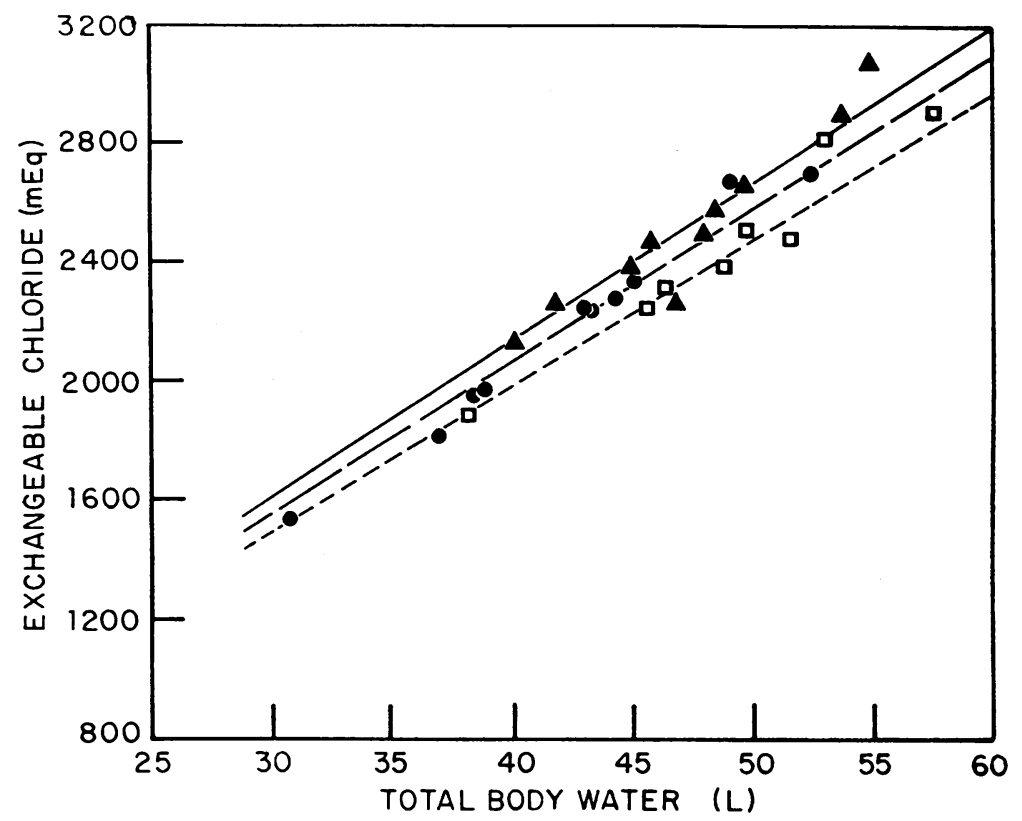

Fig. 6. LINEAR REgRESSION OF $\mathrm{Cl}_{L_{e}}$ AgAinst TBW FOR EACH OF 3 GROUPS. $\Delta$ represent fat men; $\bullet$, average men; and $\square$, thin men. 
content, as could the differences between obese and normal women.

In order to test for the presence in our subjects of variations in $\mathrm{Cl}_{e}$ associated with obesity, the regression $\mathrm{Cl}_{\mathrm{e}}$ against TBW was examined for 3 groups of subjects: a) those less than 55 per cent water by weight, who were considered fat; b) those from 55 to 60 per cent water by weight, who were considered average; and c) those more than 60 per cent water by weight, who were considered thin. Regression lines were computed for these groups, and are shown with the corresponding points in Figure 6 . These regression lines are significantly different $(\mathrm{p}<.01)$.

A more informative graphic presentation is made by comparing the ratio $\mathrm{Cl}_{\mathrm{e}}$ : TBW, which refers $\mathrm{Cl}_{\mathrm{e}}$ to TBW as an index of lean body mass, with the ratio TBW : weight, used here strictly as an index of obesity. In health, this latter ratio can be translated into fat: weight by the expression: Fat/weight $=1-(\mathrm{TBW} /$ wt $\times 0.72)$, which is derived from the Pace-Rathbun formula (17).

This comparison, $\mathrm{Cl}_{\mathrm{e}}$ : TBW against TBW: weight, is seen in Figure 7. The regression line is shown with 95 per cent confidence limits for individual values. An increase in fat content, as shown by a decrease in TBW : weight, is associated with an apparent increase in the ratio $\mathrm{Cl}_{\mathbf{e}}$ : TBW.

As Strauss, Lamdin, Smith, and Bleifer (18, 19) have pointed out, sodium excretion and retention are related in a definite way to dietary salt intake. Each day's salt intake is excreted more or less exponentially over several succeeding days. Since our values for $\mathrm{Cl}_{e}$ were obtained in men on a free-choice diet, it is possible that the regression shown in Figure 7 is at least partially related to differences in salt intake. Further elucidation of this point will await the measurement of $\mathrm{Cl}_{e}$ and TBW under circumstances that control this variable.

It may be pertinent to list other possible reasons for this apparent increase in the ratio $\mathrm{Cl}_{\mathrm{e}}$ : TBW in obese men. Increase in the mean size of fat cells may be associated with an increase in the ratio of extracellular to total water in fat tissue. Also, obesity may be associated with a small change in the composition of that portion of the lean body mass that is not part of the fat depots. Further, it is possible that the intracellular chloride may vary sufficiently to cause a slight variation in exchangeable chloride, such as that seen in our data and the data from the literature. Lastly,

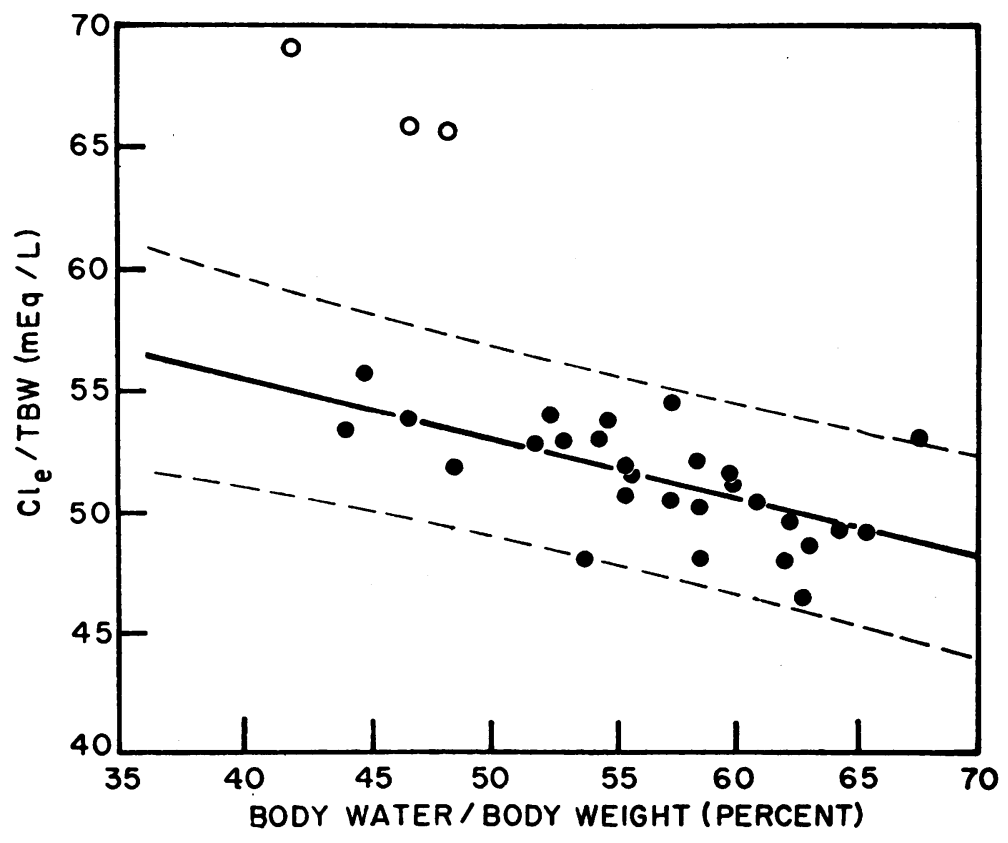

Fig. 7. Linear Regression of $\mathrm{CL}_{\mathrm{e}}$ : TBW against TBW: weight. 95 per cent confidence limits for individual values are shown. 


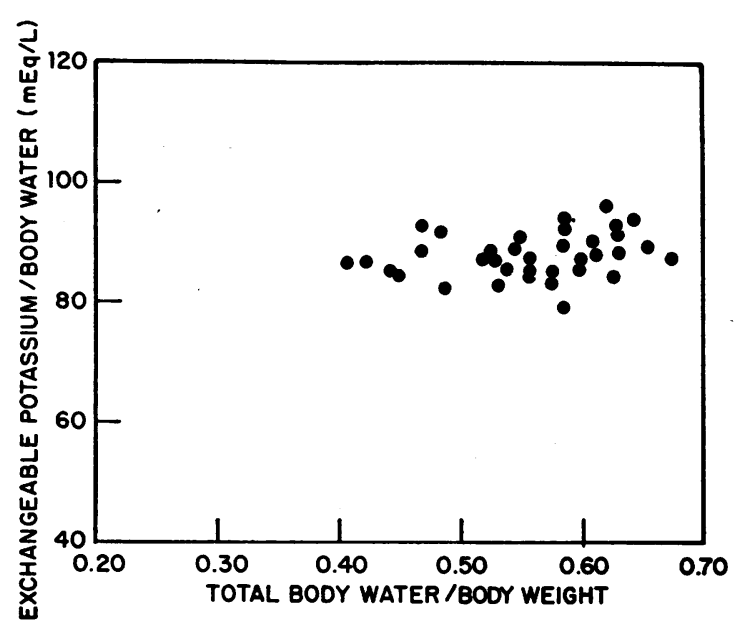

Fig. 8. Relationship of $\mathrm{K}_{\mathrm{e}}$ : TBW to TBW: weight.

the validity of the use of bromide as a chloride tracer has not been conclusively established, and the difference seen may be due to a difference in the distribution of bromide relative to chloride in the obese as against the lean subject.

Ljunggren (16) also concluded that the sex difference evident in the comparison $K_{e}$ against weight could be eliminated by means of the multiple regression of $\mathrm{K}_{e}$ on TBW and weight. He
TABLE II

Comparison of 3 groups of men

\begin{tabular}{ccc}
\hline \multicolumn{1}{c}{ Group } & $\mathrm{K}_{\mathrm{e}}: \mathrm{TBW}$ & $\mathrm{SD}$ \\
\hline $\begin{array}{l}\text { Randomly } \\
\text { selected } \\
\mathrm{n}=21\end{array}$ & $m E q / L$ & \\
$\begin{array}{l}\text { Obese } \\
\mathrm{n}=8 \\
\begin{array}{l}\text { Muscular } \\
\mathrm{n}=6\end{array}\end{array}$ & 86.4 & \pm 3.71 \\
\hline
\end{tabular}

concluded that the sex differences evident in his comparisons could be explained on the basis of differences in fat content between men and women, and between men and thin women on the one hand, and obese women on the other.

In order to test the relationship of $\mathrm{K}_{\mathrm{e}}$ to $\mathrm{TBW}$ for the presence of an obesity-dependent correlation, our group $(n=35)$ was once again divided into the same 3 groups, fat, average, and thin, with respect to TBW : weight ratio. The regressions of $K_{e}$ on TBW in these 3 groups were calculated and were not significantly different. The comparison $\mathrm{K}_{\mathrm{e}}$ : TBW against TBW: weight is seen in Figure 8. No regression seems apparent.

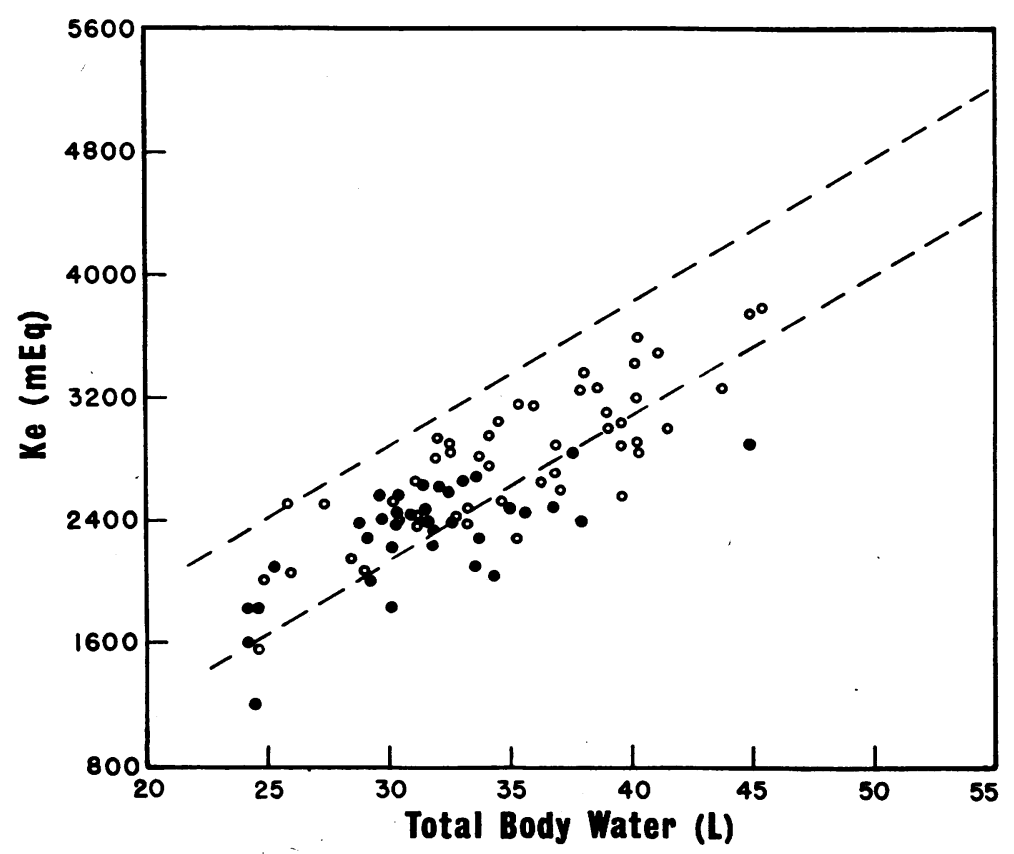

Fig. 9. Data for $\mathrm{K}_{\mathrm{e}}$ against TBW. For data from the literature, represent healthy men, and o, healthy women. 95 per cent confidence limits are shown for individual values (not shown here) of our data. 
Our group of subjects included 6 muscular weight-lifters, each more than 60 per cent water by weight. These men will be referred to as the muscular group, and are compared with the obese group $(n=8)$ and the randomly selected group $(n=21)$ in Table II. It is seen that the randomly selected group and the obese group have essentially the same mean $K_{e}$ : TBW ratio and essentially the same variation about the mean. The mean $\mathrm{K}_{\mathrm{e}}$ : TBW ratio in the muscular group, however, is more than 2 standard deviations higher than the means of the other groups, indicating that this is a distinct difference. Thus, in our group of men, no obesity-dependent difference in $\mathrm{K}_{\mathrm{e}}$ : TBW ratio was apparent; but a distinct difference in $\mathrm{K}_{\mathrm{e}}$ : TBW ratio was associated with muscular hypertrophy.

The individual confidence limits for the data in our series of men are compared with the available data for simultaneously determined $\mathrm{K}_{\mathrm{e}}$ and TBW in Figure 9. The 95 per cent confidence limits for our 35 subjects are shown. The available data $(3,6,7,20-22)$ are plotted. It is seen that the bulk of the data for men fall within our 95 per cent limits; of the values for women, however, only about half fall within our 95 per cent limits. It seems likely that there are sex differences in the $\mathrm{K}_{\mathrm{e}}$ : TBW ratio that cannot be eliminated by systems of reference tending to control only the obesity variable. It seems more likely that a difference in $\mathrm{K}_{\mathrm{e}}$ : TBW ratio between men and women is associated with the differing degree of muscular development usually seen.

\section{SUMMARY}

Total body water, total exchangeable potassium $\left(\mathrm{K}_{\mathrm{e}}\right)$, and total exchangeable chloride $\left(\mathrm{Cl}_{\mathrm{e}}\right)$ were estimated in a group of 35 healthy men of widely varying degrees of fatness, by use of tritiated water, $\mathrm{K}^{42}$, and $\mathrm{Br}^{82}$ as tracers. The methods used permitted these measurements with isotope doses such that the radiation dose was only 0.16 rad. The values for $\mathrm{K}_{\mathrm{e}}$ and $\mathrm{Cl}_{\mathrm{e}}$ were compared with those for total body water. A high degree of correlation was found for both of these regressions. Correlation coefficients were 0.96 and 0.95 , respectively. In addition, a regression was seen that tended to show a higher $\mathrm{Cl}_{\mathrm{e}}$ : total body water (TBW) ratio associated with obesity. For 10 fat men each less than 55 per cent water by weight, $\mathrm{Cl}_{\mathrm{e}}$ : TBW was $53.0 \mathrm{mEq}$ per liter. For 10 average men between 55 per cent and 60 per cent water by weight, $\mathrm{Cl}_{\mathrm{e}}$ : TBW was $51.5 \mathrm{mEq}$ per liter. For 8 lean men containing more than 60 per cent water by weight, $\mathrm{Cl}_{\mathrm{e}}$ : TBW was $49.3 \mathrm{mEq}$ per liter. Although these differences are statistically significant $(0.01>p>0.005)$, it is not possible to conclude that the total exchangeable chloride was proportionately increased in these men, since the values for $\mathrm{Cl}_{\mathrm{e}}$ were determined by observing the distribution of $\mathrm{Br}^{82}$, which can only give approximate values for $\mathrm{Cl}_{\mathrm{e}}$. The relationship between $\mathrm{K}_{\mathrm{e}}$ and TBW, on the other hand, was independent of the degree of obesity.

There was a significant difference in the ratio $\mathrm{K}_{\mathrm{e}}$ : TBW between 6 very muscular subjects, all weight-lifters, and the remainder of the group. The data are discussed and are compared with data from the literature.

\section{ACKNOWLEDGMENTS}

We wish to thank Dr. I. S. Edelman, of the University of California Medical School, for his helpful advice and assistance during the early portion of this work.

\section{REFERENCES}

1. Weir, E. G. Determination of the total chloride content of animals following administration of sodium bromide. Amer. J. Physiol. 1939, 127, 338.

2. Weir, E. G. Further observations on total chloride content. The relation between body fat and body chloride. Amer. J. Physiol. 1940, 130, 608.

3. Corsa, L., Jr., Olney, J. M., Jr., Steenburg, R. W., Ball, M. R., and Moore, F. D. The measurement of exchangeable potassium in man by isotope dilution. J. clin. Invest. 1950, 29, 1280.

4. Cheek, D. B., and West, C. D. An appraisal of methods of tissue chloride analysis: The total carcass chloride, exchangable chloride, potassium and water of the rat. J. clin. Invest. 1955, 34, 1744.

5. Muldowney, F. P. The relationship of total red cell mass to lean body mass in man. Clin. Sci. 1957, $16,163$.

6. Muldowney, F. P., Crooks, J., and Bluhm, M. M. The relationship of total exchangeable potassium and chloride to lean body mass, red cell mass and creatinine excretion in man. J. clin. Invest. 1957, $36,1375$.

7. McMurrey, J. D., Boling, E. A., Davis, J. M., Parker, H. V., Magnus, I. C., Ball, M. R., and Moore, F. D. Body composition: simultaneous determination of several aspects by the dilution principle. Metabolism 1958, 7, 651 . 
8. O'Meara, M. P., Birkenfeld, L. W., Gotch, F. A., and Edelman, I. S. The equilibration of radiosodium $\left(\mathrm{Na}^{24}\right)$, radiopotassium $\left(\mathrm{K}^{2}\right)$, and deuterium oxide $\left(\mathrm{D}_{2} \mathrm{O}\right)$ in hydropic human subjects. J. clin. Invest. 1957, 36, 784.

9. Boling, E. A. Improved plastic well scintillators for beta counting. Research and development technical report USNRDL-TR-230. San Francisco, U. S. Naval Radiological Defense Laboratory, 1958.

10. Boling, E. A. Improved plastic well scintillators for beta counting. Determination of exchangeable potassium in man using low doses of isotope. Int. J. appl. Radiat. 1959, 5, 293.

11. Chaney, A. L. Syringe attachment for accurate volumetric work in Industrial and Engineering Chemistry, analyt. ed. 1938, 10, 326.

12. Leibman, J., Gotch, F. A., and Edelman, I. S. Tritium assay by liquid scintillation spectrometry. Comparison of tritium and deuterium oxides as tracers for body water. Circulat. Res. 1960, 8, 907.

13. Sanderson, P. H. Potentiometric determination of chloride in biological fluids. Biochem. J. 1952, 52, 502.

14. Robinson, C. V., Arons, W. L., and Solomon, A. K. An improved method for simultaneous determination of exchangeable body sodium and potassium. J. clin. Invest. 1955, 34, 134.

15. Edelman, I. S., Olney, J. M., James, A. H., Brooks,
L., and Moore, F. D. Body composition: studies in the human being by the dilution principle. Science 1952, 115, 447.

16. Ljunggren, $H$. Studies on body compositions with special reference to the composition of obesity tissue and non-obesity tissue. Acta endocr. (Kbh.) 1957, 25, Suppl. 33.

17. Pace, N., and Rathbun, E. N. Studies on body composition. III. The body water and chemically combined nitrogen content in relation to fat content. J. biol. Chem. 1945, 158, 685.

18. Strauss, M. B. Body Water in Man. The acquisition and maintenance of the body fluids. Boston, Little, Brown, 1957.

19. Strauss, M. B., Lamdin, E., Smith, W. P., and Bleifer, D. J. Surfeit and deficit of sodium. A kinetic concept of sodium excretion. A.M.A. Arch. intern. Med. 1958, 102, 527.

20. Ljunggren, H., Ikkos, D., and Luft, R. Studies on body composition. I. Body fluid compartments and exchangeable potassium in normal males and females. Acta endocr. (Kbh.) 1957, 25, 187.

21. Ljunggren, H., Ikkos, D., and Luft, R. Studies on body composition. II. Body fluid compartments and exchangeable potassium in obese females. Acta endocr. (Kbh.) 1957, 25, 199.

22. Deane, N., and Smith, H. W. The distribution of sodium and potassium in man. $\mathrm{J}$. clin. Invest. 1952, 31, 197. 